\title{
Research on Economic Bearing Capacity of Farmers to Agricultural Irrigation Water Prices in the Ebinur Lake Basin
}

\author{
Lei Wang ${ }^{1,2,3}$, Zibibula Simayi ${ }^{1,2,3, *}$, Shengtian Yang ${ }^{1,2,3}$ and Yusuyunjiang Mamitimin ${ }^{1,2,3}$ \\ 1 College of Resource and Environment Sciences, Xinjiang University, Urumqi 830046, China; \\ wanglei2923@163.com (L.W.); yangshengtian@bnu.edu.cn (S.Y.); y_mamitimin@163.com (Y.M.) \\ 2 Key Laboratory of Smart City and Environmental Modeling of Regular Institutions of Higher Learning, \\ Xinjiang University, Urumqi 830046, China \\ 3 Key Laboratory of Oasis Ecology Ministry of Education, Xinjiang University, Urumqi 830046, China \\ * Correspondence: zibibulla3283@sina.cn
}

Received: 5 March 2019; Accepted: 8 April 2019; Published: 11 April 2019

\begin{abstract}
The Ebinur Lake Basin is one of the few lakes in the arid area of northwest China where water shortages have always been an important factor hindering development. Therefore, this study takes as its objective an investigation of water prices as the main economic factor that restricts the sustainable utilization of water resources to explore the economic affordability of water prices for farmers. Furthermore, the study attempts to determine the appropriate range of prices for water price reform. In this study, a questionnaire was designed to survey 210 agricultural water users in Wenquan County, Bole City, and Jinghe County, areas where agricultural activities are relatively concentrated in the vicinity of the Ebinur Lake Basin. Based on the data from the field survey, the range of economic affordability for farmers in the Ebinur Lake Basin was categorized by the ELES model; according to the analysis method of water tolerability index, a suitable water price standard for farmers' reform was obtained. The results show that (1) $97 \%$ of the farm households have the ability to pay irrigation water prices and only $3 \%$ do not have the ability to pay and (2) economically affordable water prices for farm households range from 79 to $143 € / \mathrm{hm}^{2}$, the latitude for raising water prices is $64 € / \mathrm{hm}^{2}$, and the adjustable range of unit water pricing is between 0.014 and $0.042 € / \mathrm{m}^{3}$. It can be seen that increasing water prices is feasible.
\end{abstract}

Keywords: the Ebinur Lake Basin; irrigation price; farmers; bearing capacity

\section{Introduction}

Water resources are not only indispensable natural resources for human survival and evolution, but also an environmental resource necessary for the survival of all life on Earth. Given the continued progress of the social economy, the acceleration of urbanization processes, and the frequent occurrence of global climate anomalies, the crisis regarding water resources has gradually intensified; presently and in the future, the shortage of water resources has become an obstacle to the development and utilization of water resources in China and is also an important factor restricting the sustainable development of China's economy and society [1,2]. China is a large agricultural country, and the problem of agricultural water use cannot be ignored as in the process of agricultural modernization, deterioration of rural ecological systems, and water pollution occur frequently [3,4]. As the main economic means of agricultural water conservation, water pricing influences farmers' irrigation behavior and promotes achievement of agricultural water conservation by means of price leverage; therefore, strengthening the study of rational water price determination has far-reaching strategic significance for sustainable development of regional water resources [5-7]. At the 19th National 
Congress of the Communist Party of China, General Secretary Xi Jinping first put forward the idea of socialism with Chinese characteristics in the new era, stating accelerating the construction of an ecological civilization as the key task for economic work in 2018. He proposed that to make the waters green and the mountains golden and silver, we should first restore the green waters and the mountains, carry out major projects for ecological protection and restoration defined in the 13th Five-Year Plan, launch large-scale land greening, reform the system of ecological civilization, establish and improve the property rights system of natural resources assets, and establish a market-oriented and diversified ecological compensation mechanism.

The Ebinur Lake Basin is located in the southwestern margin of the Junggar Basin in northern Xinjiang; the total area of the basin is approximately $50,621 \mathrm{~km}^{2}$. The basin includes the Kuitun River, Jinghe River, and Boertala River areas and a small river area in southern Toli [8]. The Ebinur Lake Basin exhibits a typical temperate and arid continental climate with low precipitation, large amounts of evaporation, abundant sunshine, and intense climate change. The annual average precipitation is 116.0-169.2 mm, and at present, only the Boltala River and Jinghe River are injected; the water volume has been greatly reduced [9]. It can be seen that the irrigation water source in the irrigation area has the characteristics of scarcity and a natural monopoly, so the water pricing for this irrigation area should not only take into account the economic and ecological cost of water, but also consider the affordability of water prices for farmers [10].

The study of irrigation water prices abroad appeared for the first time in the 1970s. The main theories include scarcity of water resources and utility value theory. As believed by Abuzeid, during the formulation and implementation of water prices, in addition to farmers' perspectives, efficiency and equity should also be considered as basic principles for irrigation water pricing; it would contribute to reduction of irrigation water use [11]. Tyler and Joshua calculated seasonal water pricing using a non-integer programming model, and they determined the implementation of seasonal water pricing to be beneficial for the rational allocation of water resources [12]. Latinopoulos indicated that the pricing model for agricultural irrigation water in the eastern United States is "service cost + user affordability", while in the western United States, it is "service cost + complete market" [13]. Yaweny believed that the study of the price elasticity coefficient of water demand must be based on large amounts of data; this may improve effectiveness of studying water resource management and enhance the reliability of price elasticity [14]. Kunimitsu proposed to achieve an optimal allocation of water resources by using mathematical models, this method must be based on the opportunity cost to achieve the goal of reducing irrigation water use, thereby alleviating the contradiction and conflict of water use [15]. A basic methodological framework was set by Kanakoudis et al., it aimed at guaranteeing the reliable calculation of the full water cost and helping to develop an effective and socially just water pricing policy [16]. In the study by Kanakoudis and Gonelas, an urban water supply, distribution system, and response of consumption to the increased water price were applied into the full water cost principle $[17,18]$. Kanakoudis and Gonelas examined the factors affecting the residential water demand level in the city of Kozani in Greece, they expected to determine and record the overall reaction of consumers to the changes in water prices because of implementing the full water cost principle [19]. Also, Kanakoudis and Gonelas analyzed the full water cost integration in water price as well as the consumers' response to water price changes; they hoped to find the optimal balance point in Kozani's water distribution system under increased water price [20]. Domestic water price research began to increase mainly after the 1990s. General Secretary Xi Jinping presented the concepts of water-saving priority, space balance, systematic management, and evenhanded efforts as a scientific guide for water conservancy work, including new requirements and tasks for water control in the new era and pointing out the direction and manner for strengthening water controls and ensuring water safety [21]. Many scholars in China have performed research on the determination of water resources value and reasonable water pricing. According to Luo and Yuan, the main approach to balancing interests was to establish a reasonable water pricing system; in addition, during water price adjustments, the affordability for farmers should be taken into account; this would help achieve the 
adjustment of the agricultural production structure and the promotion of water-saving practices [22]. Taking Zhangye City as an example, Liu et al. analyzed the impact of water price reform on the economy by using the CGE (computable general equilibrium) model; they concluded that water conservation benefits could be achieved through price leveraging [23]. As pointed out by Wang et al., a scientific and reasonable water pricing system guaranteed the implementation of a benign operation mechanism for farmland water conservancy projects. Furthermore, in the adjustment of water prices, not only the costs of water supplies but also the affordability for farmers should be considered [24]. Yin and Cai also reported the contribution of a scientific and reasonable water pricing system to the sustainable use of water resources, and farmers are the main users of agricultural irrigation, hence their attitudes to and acceptance of water price changes should not be ignored in the process of formulating and implementing water price policy [25]. The study by Li et al. was performed on the comprehensive control area of groundwater overexploitation in Hebei Province; the ability of farmers to bear a range of water prices was considered, and a binary logistic model was used to study the factors that impacted on farmers' willingness to save water in the context of water price reform [26].

As an effective economic means of water resources management, water prices play a vital role in promoting water conservation, regulating water demand and allocating water resources $[27,28]$. Considering farmers' affordability is the key factor in water price reform and policy formulation, how to formulate a reasonable water price to ensure the affordability by farmers, which is important for improving the efficiency of water resources utilization and promoting sustainable development of water resources. At present, in the context of water price reform and from the perspective of affordability, the author's research group believes that it will be more significant to study the economic affordability of irrigation water prices for farmers. In this study, Wenquan County, Bole City, and Jinghe County, located in the Ebinur Lake Basin, were selected as sample areas. Through the analysis of economic affordability for farmers, the acceptable price range of water prices for farmers was determined to improve their water use efficiency.

\section{Research Method and Date Sources}

\subsection{Research Method}

\subsubsection{ELES Model}

The extended linear expenditure system (ELES) was used in this study. This model is a demand function system and is generally used to study consumption structures. This paper uses the ELES to analyze the household consumption expenditures, and can not only analyze the income level and consumption pattern of households, but also reflect the objective economic affordability for other living and production consumption besides meeting basic living needs, to some extent. The basic form of ELES model is [29]

$$
p_{\mathrm{i}} q_{i}=p_{i} r_{i}+\beta_{i}\left(I-\sum_{j=1}^{n} P_{j} r_{j}\right)(i, j=1,2, \ldots, n)
$$

In the formula, $q_{\mathrm{i}}$ represent the actual demand of consumers for the $i$ th commodity, $r_{i}$ represents the basic demand of consumers for the $i$ th commodity, $p_{i}$ represents the price of the $i$ th commodity, $\beta_{i}$ represents the marginal inclination of consumers to consume the $i$ th commodity, and I represents the disposable income of the consumers.

The economic meaning of this model can be divided into three levels: first, the income levels and commodity prices dominate the demand by consumers for various commodities during a certain period of time; second, the basic demand for non-basic items constitutes the quantity demanded by consumers for various commodities; and third, income level has almost no effect on basic demands, and only when the basic demands are met will there be demands for non-basic items by consumers.

According to the classification method in the statistical yearbook, this paper divides household living expenditures into six categories: food, education, medical, transportation, household equipment, 
and other expenditures. For cross-sectional data, the least squares method used in the ELES model is commonly used, in which $p_{\mathrm{i}} r_{i}$ and $\sum p_{j} r_{j}$ represent constants. For this case, the mathematical transformation of Formula (1) is carried out as

$$
\begin{gathered}
\alpha_{i}=p_{i} r_{i}-\beta_{i} \sum_{j=1}^{n} p_{j} r_{j}(i, j=1,2, \ldots, n) \\
p_{i} q_{i}=\alpha_{i}+\beta_{i} I(i=1,2, \ldots, n) \\
p_{i} r_{i}=\alpha_{i}+\beta_{i} \sum_{i=1}^{n} \alpha_{i} /\left(1-\sum_{i=1}^{n} \beta_{i}\right)(i=1,2, \ldots, n)
\end{gathered}
$$

Estimated values in Formula (3) can be calculated by the least squares method, and then the parameters of the model can be determined. The basic form of the ELES model is determined, that is, the income elasticity of peasant households for various commodities can be obtained by formula transformation or the degree of demand for various commodities relative to income under a condition of constant prices. The formula to calculate this is

$$
\eta_{\mathrm{i}}=\frac{\partial q_{i}}{\partial I} \circ \frac{I}{q_{i}}=\beta_{i} \frac{I}{p_{i} q_{i}}(i=1,2, \ldots, n)
$$

Therefore, the marginal inclination to consume, the basic demand expenditure, and the elasticity of demand income can be calculated by Formulas (2)-(5); then, the structure of farmer living consumption can be analyzed. On this basis, we can further analyze the level of different farmers' ability to pay for irrigation water at a given price and define groups of farmers with 'no capacity to pay', 'a certain capacity to pay', and 'a capacity to pay'; then, we can determine the proportion of different types of farmers in the total sample [30].

\subsubsection{Water Price Tolerance Index Analysis}

The water price bearing capacity analysis method is a commonly used research method to measure water price bearing capacity in China. Tolerance describes people's tolerance to maintain a certain water price, and has a certain range. All walks of life have mathematic models to calculate water price bearing capacity. Water price bearing index is a method to measure water price bearing capacity from the perspective of water users, and it is widely used in the study of endurance for farmers' water price [31].

In this study, mainly through investigating the inputs and outputs of farm agricultural production, including fertilizer, seed, insecticide, weeding, mechanized cultivation and water fees, the proportion of water expenditure to agricultural production cost, output value, and income can be calculated. On this basis, this proportion is compared with a reasonable range based on domestic achievements or experience; then, the affordability of water prices should be determined in accordance with local conditions to institute corresponding water price reform measures in a comparative manner.

The method of water price bearing index is simple and practical. It can clearly understand the farmer's agricultural production and operation activities directly related to irrigation water price, especially the cost composition and profit situation. In practical research, in order to fully reflect the affordability of farmers' water price, scholars generally choose multiple indicators to measure the affordability according to research needs and data availability. Considering that there are many investment projects in irrigation for agricultural production and that the impact on outputs is complex, this paper assumes that all other factors remain unchanged and considers the water price standard as a dependent variable; then, analysis of the dynamic changes of the main indicators to observe the adaptability of income and expenditure structures to water price adjustments is performed. The specific analysis method of the farm household affordability index can be divided into the following four main indicators: (1) the proportion of total water cost to total cost; (2) the proportion of total water cost to 
total output value; (3) the proportion of total water cost to net income; and (4) the proportion of total water cost to the benefits of increasing irrigation production [32].

\subsection{Data Sources}

The study was based on data collected from 210 farm household interviews conducted in August 2017. Two villages and one corps in Wenquan County, one village and two corps in Bole City, and one village and one corps in Jinghe County around the Ebinur River Basin in Xinjiang were selected as survey areas. The subjects were ordinary farmers and village cadres located in the survey area; the survey method was a household survey. A total of 214 questionnaires were obtained, 210 of which were valid, including 80 from Wenquan County, 77 from Bole City, and 53 from Jinghe County. The main items in the questionnaire include the basic status of farmers, farmer income and expenditures, irrigation water used, and agricultural production in terms of inputs and outputs.

Among 210 valid samples surveyed, men accounted for an absolute proportion, with $90 \%$ in Wenquan County, $96 \%$ in Bole City, and $89 \%$ in Jinghe County. Among the farmers interviewed, most of them were between 40 and 59 years old, with $74 \%$ in Wenquan County, $73 \%$ in Bole City, and $79 \%$ in Jinghe County. The educational level of the three regions is mainly primary or junior middle school, including $85 \%$ in Wenquan County, $82 \%$ in Bole City, and $88 \%$ in Jinghe County. The proportion of agricultural income in the three places is mainly between $75 \%$ and $100 \%$. Wenquan County accounts for $80 \%$, Bole City for $91 \%$, and Jinghe County for $85 \%$. With regard to irrigation, most of the farmers in the three areas use drip irrigation, which is a water-saving irrigation method. Only a few farmers use flooding irrigation.

Farmers in Wenquan County, Bole City, and Jinghe County were selected as the subjects of this experiment (Figure 1). The reason for their selection was that these three regions have relatively concentrated agricultural activities around the Ebinur Lake Basin and that a comparative study of them would be scientific and applicable.

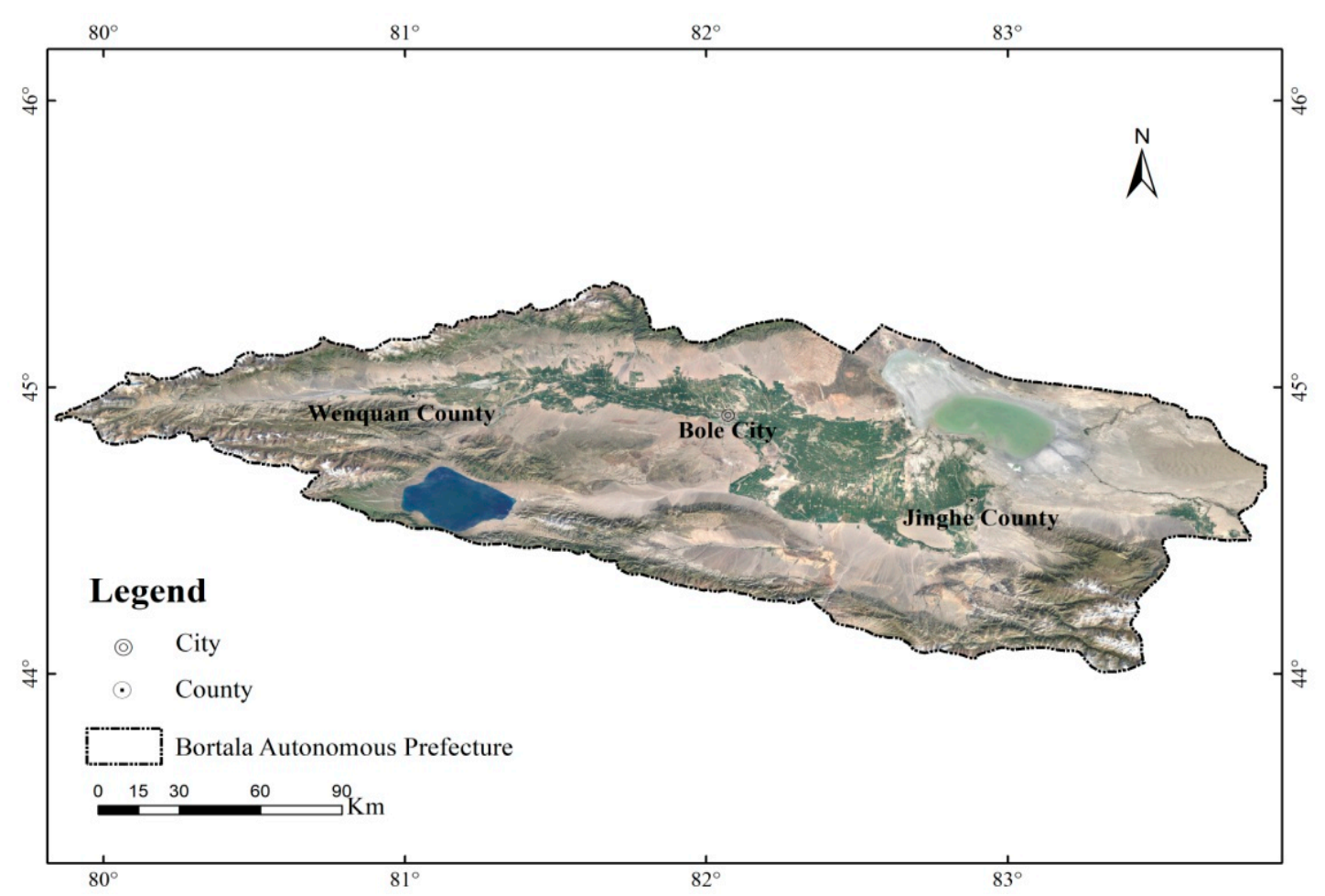

Figure 1. Sample plot of the Ebinur Lake Basin. 


\section{Results and Analysis}

\subsection{Economic Bearing Capacity Analysis and Standard Definition of the Irrigation Water Price of Farmers}

\subsubsection{Income and Expenditure of Farm Households}

The income and expenditure of rural households in the irrigation areas around the Ebinur Lake Basin are shown in Table 1. It can be seen that the average per capita net income of farm households is $2870.94 €$ and that the annual per capita consumption expenditure is $2210.38 €$, which is equivalent to $76.99 \%$ of the annual per capita net income. Food expenditures account for $33.98 \%$ of consumption, or $26.16 \%$ of annual net income per capita, which is the highest of all expenditures. The next largest expense is for medical expenditures, followed by education and transportation expenses; however, the proportion of household equipment expenses is low, and the lowest proportion is for other expenditures. The annual per capita irrigation water expenditure for farmers is $6.44 €$, accounting for only $0.22 \%$ of the per capita net income.

Table 1. Income and expenditure of peasant households.

\begin{tabular}{cccc}
\hline Project & Money $(\boldsymbol{€})$ & $\begin{array}{c}\text { Proportion of Living } \\
\text { Expenditure (\%) }\end{array}$ & $\begin{array}{c}\text { Proportion of per } \\
\text { Capita Net Income (\%) }\end{array}$ \\
\hline Annual per capita net income & 2870.94 & - & 100 \\
\hline $\begin{array}{c}\text { Annual per capita living } \\
\text { expenditure }\end{array}$ & 2210.38 & 100 & 76.99 \\
\hline Food expenditure & 751.05 & 33.98 & 26.16 \\
\hline Education expenditure & 362.13 & 16.38 & 12.61 \\
\hline Medical expenditure & 437.28 & 19.78 & 11.22 \\
\hline Traffic expenditure & 322.02 & 14.57 & 7.63 \\
\hline $\begin{array}{c}\text { Household equipment } \\
\text { expenditure }\end{array}$ & 218.95 & 9.91 & 4.14 \\
\hline $\begin{array}{c}\text { Other expenditures } \\
\text { Annual per capita expenditure on } \\
\text { irrigation water price }\end{array}$ & 118.95 & 5.38 & 0.22 \\
\hline
\end{tabular}

\subsubsection{Basic Consumer Demand Expenditure of Farm Households}

According to the ELES model defined by the payment capacity level, the parameters of the model are estimated by EViews 8.0 software (Quantitative Micro Software, USA). Table 2 presents-except for other expenditures and net income-no statistical significance exists for the estimated value of beta, but the estimated values for alpha and beta, related to remaining living expenditures and net income, do have statistical significance. Excluding other expenditures, there is a functional relationship between the various consumption of living expenditures and per capita net income. The reason for this finding may be that the cost of other expenditures is still unstable and the relationship between net income and expenditure is variable. 
Table 2. Parameter estimation of ELES model.

\begin{tabular}{ccccc}
\hline \multirow{2}{*}{ Living Expenditure } & \multicolumn{2}{c}{$\begin{array}{c}\text { A (Basic Consumption } \\
\text { Expenditure) }\end{array}$} & \multicolumn{2}{c}{$\begin{array}{c}\text { B (Marginal Propensity } \\
\text { to Consume) }\end{array}$} \\
\cline { 2 - 5 } & Estimated Value & Prob. & Estimated Value & Prob. \\
\hline Food expenditure & 3853.36 & 0.0000 & 0.0455 & 0.0011 \\
\hline Education expenditure & 2750.91 & 0.0000 & 0.0956 & 0.0000 \\
\hline Medical expenditure & 2235.77 & 0.0000 & 0.2929 & 0.0000 \\
\hline Traffic expenditure & 3235.96 & 0.0000 & 0.0493 & 0.0007 \\
\hline Household equipment expenditure & 2510.84 & 0.0000 & 0.0747 & 0.0000 \\
\hline Other expenditures & 2543.65 & 0.0000 & -0.0018 & 0.4309 \\
\hline Total & $17,130.49$ & - & 0.5562 & - \\
\hline
\end{tabular}

The elasticity between basic consumption demand expenditures and demand income of farmers can be obtained by substituting the model parameters estimated in Table 2 into the above-mentioned formula. Table 3 presents the total basic consumption expenditure (excluding other expenditures) of farm households is $1815.04 €$, which is roughly consistent with the annual per capita balance of income and expenditure ranging between $1317.11 €$ and $1975.66 €$. In addition, the basic demand expenditures in descending order are food, medical, education, household equipment, and transportation expenditures. Among these, food expenses account for $35.16 \%$ of the total basic demand, meaning that the Engel coefficient is (it is the proportion of total food expenditure to total personal consumption expenditure) 0.4 , this value is small, showing that food expenditures account for less and other expenditures account for more, so the income is higher, living standards of farmers are better. The overall marginal tendency of farmers to consume is 0.5580 , indicating that $55.80 \%$ of the additional income of farmers is spent on living consumption expenditures. These results are consistent with the previous higher level of consumption mentioned. The income elasticity of these expenditure items is between 0 and 1 , which belongs to the necessities of life for each farmer.

Table 3. Expenditure of basic consumption demand and elasticity of demand income.

\begin{tabular}{cccc}
\hline Living Expenditure & $\begin{array}{c}\text { Marginal Propensity } \\
\text { to Consume }\end{array}$ & $\begin{array}{c}\text { Basic Demand } \\
\text { Expenditure/€ }\end{array}$ & $\begin{array}{c}\text { Income Elasticity } \\
\text { of Demand }\end{array}$ \\
\hline Food expenditure & 0.0455 & 638.16 & 0.2047 \\
\hline Education expenditure & 0.0956 & 274.46 & 0.4310 \\
\hline Medical expenditure & 0.2929 & 546.42 & 0.7406 \\
\hline Traffic expenditure & 0.0493 & 141.54 & 0.2493 \\
\hline Household equipment expenditure & 0.0747 & 214.46 & 0.3770 \\
\hline Total & 0.5580 & 1815.04 & - \\
\hline
\end{tabular}

\subsubsection{Definition Criteria of Ability to Pay}

Based on the calculations of basic consumption demand expenditures of farmers, shown in Table 3 , the definition criteria of farmers' ability to pay can be determined, as shown in Table 4 . When the per capita net income of farmers is below $638 €$ per year, they have no ability to pay for irrigation water; when the per capita net income is between $638 €$ and $1815 €$, farmers have a certain ability to pay for irrigation water; and when the per capita income is higher than $1815 €$, farmers have a complete ability to pay for irrigation water. Approximately $86 \%$ of the 210 households surveyed have the ability to pay for irrigation water, approximately $11 \%$ have a certain ability to pay for irrigation water, and only approximately $3 \%$ have no ability to pay for irrigation water. Therefore, this $3 \%$ of households is the focus of future irrigation water price reform in the Ebinur Lake Basin. 
Table 4. Definition of farmers' ability to pay theirrigation water price.

\begin{tabular}{ccc}
\hline Annual per Capita Net Income $(\boldsymbol{(})$ & Paying Ability & Proportion of Farm Households \\
\hline$<638$ & no ability to pay & $3.3 \%$ \\
$638-1815$ & certain ability to pay & $10.5 \%$ \\
$>1815$ & complete ability to pay & $86.2 \%$ \\
Total & - & $100 \%$ \\
\hline
\end{tabular}

\subsection{Dynamic Analysis of the Adjustment of Irrigation Water Price Standard for Farmers}

\subsubsection{Water Expenditure Level}

Through this research and development, it is found that wheat and cotton are mainly planted in the irrigation area around the Ebinur Lake Basin. Therefore, this paper uses these two typical crops as examples for studying the input and output benefits of the irrigation area for crops, as shown in Tables 5 and 6.

Table 5. Average production costs of crops (wheat and cotton) $\left(€ / \mathrm{hm}^{2}\right)$.

\begin{tabular}{cccccccccc}
\hline Seed & $\begin{array}{c}\text { Plastic } \\
\text { Film }\end{array}$ & $\begin{array}{c}\text { Chemical } \\
\text { Fertilizer }\end{array}$ & Pesticides & Weed & Water-Price & $\begin{array}{c}\text { Tractor- } \\
\text { Ploughing }\end{array}$ & $\begin{array}{c}\text { Irrigation and } \\
\text { Drainage }\end{array}$ & Other & Total \\
\hline 101 & 49 & 524 & 47 & 56 & 91 & 212 & 257 & 145 & 1482 \\
$6.8 \%$ & $3.3 \%$ & $35.4 \%$ & $3.2 \%$ & $3.8 \%$ & $6.1 \%$ & $14.3 \%$ & $17.3 \%$ & $9.8 \%$ & $100 \%$ \\
\hline
\end{tabular}

Table 6. Average irrigation benefit analyses of crops (wheat and cotton) $\left(€ / \mathrm{hm}^{2}\right)$.

\begin{tabular}{ccccc}
\hline $\begin{array}{c}\text { Total Output } \\
\text { Value }\end{array}$ & Total Cost & $\begin{array}{c}\text { Net } \\
\text { Contribution }\end{array}$ & $\begin{array}{c}\text { Benefit of Irrigation } \\
\text { Yield Increase }\end{array}$ & Water Price \\
\hline 1957.62 & 1482.41 & 1326.07 & 475.21 & 90.88 \\
\hline
\end{tabular}

From Table 5, we obtain the production cost composition of the main crops in the irrigation area of the Ebinur Lake Basin. This Table demonstrates that the production costs for the main crops in the irrigation area of the Ebinur Lake Basin are largely accounted for by chemical fertilizer costs, with an input rate as high as $35.4 \%$, followed by maintenance and management costs for drainage irrigation, accounting for $17.3 \%$, and then the costs of mechanical cultivation, accounting for $14.3 \%$. At a lower level than the costs just mentioned are 'other costs' (such as rent and harvest costs), seed costs, water costs, weeding costs, and agricultural plastic film and pesticide costs, listed from highest to lowest. Water costs account for only $6 \%$ of production costs.

Table 6 shows that the total output value of the main crops in the Ebinur Lake Basin, under the current water price standard, is approximately $1957.62 € / \mathrm{hm}^{2}$, the total cost is approximately $1482.41 € / \mathrm{hm}^{2}$, the net benefit is approximately $1326.07 € / \mathrm{hm}^{2}$, the benefit of irrigation is approximately $475.21 € / \mathrm{hm}^{2}$, and the water cost is approximately $90.88 € / \mathrm{hm}^{2}$. Among these, the cost of water accounts for $4.6 \%$ of the total output value and $6.9 \%$ of the net benefit. Water prices for the current water price standard are within the affordable range for farmers in the irrigation district of the Ebinur Lake Basin.

\subsubsection{Analysis of the Range of Affordable Water Prices}

Assuming that the input and gross production value of other production factors remains unchanged except for water prices, the dynamic impact of changes in water price standards on the main indicators is analyzed. According to current research results in China, the proportion of water price to total output value, total cost, net income, and benefit of irrigation increase can be divided into appropriate ranges as follows: the ratio of agricultural water price to total output value is $5-15 \%$, the ratio of agricultural water price to total cost is $20-30 \%$, the ratio of agricultural water price to 
net effect is $10-20 \%$, and the ratio of agricultural water price to irrigation yield increase benefit is $30-40 \%$. Therefore, based on these criteria, this paper analyses the rationality of the index of water price change for the main crops and on affordability for farmers in the irrigation area of Ebinur Lake Basin. The specific analysis results are shown in Table 7.

Table 7. Simulated table of dynamic change of water price standard.

\begin{tabular}{ccccc}
\hline Water Price $\mathbf{\epsilon} / \mathbf{h m}^{\mathbf{2}}$ & $\begin{array}{c}\text { Percentage of } \\
\text { Total Output } \%\end{array}$ & $\begin{array}{c}\text { Percentage of } \\
\text { Total Cost } \%\end{array}$ & $\begin{array}{c}\text { Percentage of Net } \\
\text { Contribution \% }\end{array}$ & $\begin{array}{c}\text { Percentage } \\
\text { of Increasing } \\
\text { Irrigation \% }\end{array}$ \\
\hline 79 & 4.04 & 5.33 & 5.96 & 12.74 \\
91 & 4.64 & 6.80 & 6.85 & 14.65 \\
103 & 5.25 & 7.68 & 7.75 & 16.56 \\
115 & 5.85 & 8.57 & 8.64 & 18.48 \\
126 & 6.46 & 9.45 & 9.54 & 20.39 \\
138 & 7.06 & 10.34 & 10.43 & 22.30 \\
150 & 7.67 & 11.23 & 11.32 & 24.21 \\
162 & 8.28 & 12.11 & 12.22 & 26.12 \\
174 & 8.88 & 13.00 & 13.11 & 28.03 \\
186 & 9.49 & 13.89 & 14.00 & 29.94 \\
198 & 10.09 & 14.77 & 14.90 & 31.85 \\
209 & 10.70 & 15.66 & 15.79 & 33.77 \\
221 & 11.30 & 16.55 & 16.69 & 35.68 \\
233 & 11.91 & 17.43 & 17.58 & 37.59 \\
245 & 12.51 & 18.32 & 18.47 & 39.50 \\
257 & 13.12 & 19.20 & 19.37 & 41.41 \\
\hline
\end{tabular}

Table 7 shows that the proportion of water price to gross output value is between $4.04 \%$ and $13.12 \%$, within the appropriate range, and does not exceed the affordability level for farmers. The proportion of water price to total cost ranges from $5.33 \%$ to $19.20 \%$, it does not exceed the appropriate range, and it is within the acceptable range of farmers. The proportion of water price to net benefit is $5.96-19.37 \%$, which is not more than $20 \%$, which is acceptable and within the affordable range for farmers. Water prices account for $12.74-41.41 \%$ of the benefit of increasing irrigation yield, which basically meets the standards of the suitable range. However, when water prices rise to $257 € / \mathrm{hm}^{2}$, the proportion of water price to the benefit of increasing irrigation yield exceeds $40 \%$ of the optimum extreme value. Therefore, water prices should be maintained within this range to be within the affordable range for farmers. Furthermore, the proportion of water price to the benefit of irrigation production increases most rapidly and the proportion of water price to the total cost and net benefit essentially maintains the same trend, while the proportion of water price to the total output value increases slowly.

\subsubsection{Space Analysis of Water Price Standard Adjustment}

To ensure that the irrigation water price reform for farmers can fall within a certain affordable range, combined with the appropriate domestic scope standards, the water price is $15 \%$ of the total output value, $20 \%$ of the total cost, $15 \%$ of the net benefit, and $30 \%$ of the increased benefit of irrigation are defined as the limits. The space scope of the water price standard is introduced, and the appropriate adjustable space is determined. The specific results are shown in Table 8.

Table 8. Spatial table of water price adjustment $\left(€ / \mathrm{hm}^{2}\right)$.

\begin{tabular}{ccccccc}
\hline $\begin{array}{c}\text { Current } \\
\text { Water Price } \\
\text { Standard }\end{array}$ & $\begin{array}{c}\text { Proportion of } \\
\text { Total Output } \\
\text { of } \mathbf{1 5 \%}\end{array}$ & $\begin{array}{c}\text { Proportion } \\
\text { of Total } \\
\text { Cost of } \mathbf{2 0} \%\end{array}$ & $\begin{array}{c}\text { Proportion of Net } \\
\text { Contribution of } \\
\mathbf{1 5 \%}\end{array}$ & $\begin{array}{c}\text { Proportion of } \\
\text { Increasing } \\
\text { Irrigation of 30\% }\end{array}$ & $\begin{array}{c}\text { Suitable } \\
\text { Water Price } \\
\text { Standard }\end{array}$ & $\begin{array}{c}\text { Adjustment } \\
\text { Space of Water } \\
\text { Price Standard }\end{array}$ \\
\hline 79 & 294 & 268 & 199 & 143 & 143 & 63 \\
\hline
\end{tabular}


As seen from Table 8 , the values obtained by $15 \%$ of the total output value and $20 \%$ of the total cost are all greater than $257 € / \mathrm{hm}^{2}$, which indicates that the water price value of this proportion is higher. Fifteen percent of the water price accounted for the net benefit ratio of $199 € / \mathrm{hm}^{2}$, indicating this water price value is small, while $30 \%$ of the water price accounted for a benefit ratio of increasing irrigation production by $143 € / \mathrm{hm}^{2}$, and it is the lowest standard value. Therefore, it can be determined that the adjustment space of the water price standard should be maintained within the range of $79-143 € / \mathrm{hm}^{2}$. The most common economic means to improve the efficiency of water resources utilization is to raise water prices. Through our analysis, we see that the space for raising water price is $64 € / \mathrm{hm}^{2}$, which is far below the minimum payment level for farmers. Therefore, it is feasible to raise water prices.

After the adjustment space of the water price standard is determined, this paper performs a dynamic simulation analysis of water price standard in two stages, before and after water conservation (water price increasing), and convert it into a unit water price. Then, according to four reference indicators, a suitable standard of unit water pricing is determined. These results are shown in Tables 9 and 10.

Table 9. Dynamic simulation results of before and after water saving for water price standard.

\begin{tabular}{ccccccccccc}
\hline $\begin{array}{c}\text { Water price } \\
\left(€ / \mathrm{hm}^{2}\right)\end{array}$ & 79 & 91 & 103 & 115 & 126 & 138 & 150 & 162 & 174 & 186 \\
\hline $\begin{array}{c}\text { Before water } \\
\text { saving }\left(€ / \mathrm{m}^{3}\right)\end{array}$ & 0.014 & 0.017 & 0.018 & 0.021 & 0.024 & 0.025 & 0.028 & 0.030 & 0.032 & 0.034 \\
\hline $\begin{array}{c}\text { After water } \\
\text { saving }\left(€ / \mathrm{m}^{3}\right)\end{array}$ & 0.018 & 0.021 & 0.024 & 0.026 & 0.029 & 0.032 & 0.034 & 0.037 & 0.040 & 0.042 \\
\hline
\end{tabular}

Table 10. Suitable water price criteria under the constraints of four reference index values.

\begin{tabular}{ccccc}
\hline Current Water Price & \multicolumn{2}{c}{ Affordable Water Price $\left(\boldsymbol{\epsilon} / \mathbf{m}^{\mathbf{3}}\right)$} & \multicolumn{2}{c}{ Water Price Adjustment Space $\left(\boldsymbol{\epsilon} / \mathbf{m}^{\mathbf{3}}\right)$} \\
\hline $\boldsymbol{\epsilon}^{\mathbf{m} \mathbf{m}^{\mathbf{3}}}$ & $\begin{array}{c}\text { Before Water } \\
\text { Saving }\end{array}$ & $\begin{array}{c}\text { After Water } \\
\text { Saving }\end{array}$ & $\begin{array}{c}\text { Before Water } \\
\text { Saving }\end{array}$ & $\begin{array}{c}\text { After Water } \\
\text { Saving }\end{array}$ \\
\hline 0.014 & 0.034 & 0.042 & 0.011 & 0.018 \\
\hline
\end{tabular}

As shown in Tables 9 and 10, the current water price in the irrigation area of Ebinur Lake Basin is $0.014 € / \mathrm{m}^{3}$, within the affordable range for farmers, and $64 € / \mathrm{hm}^{2}$ of advanced space can be adjusted. The unit water price in the adjustable space is $0.011 € / \mathrm{m}^{3}$. If the current water price is taken as the standard, the unit water price after water saving measures is $0.018 € / \mathrm{m}^{3}$. The maximum tolerable unit water price is $0.042 € / \mathrm{m}^{3}$.

\section{Conclusions and Discussion}

Through the administration of questionnaires to the farmers around the Ebinur Lake Basin in Xinjiang, this paper describes the basic status of farmers in Wenquan County, Bole City, and Jinghe County and uses the ELES model to analyze the overall income and expenditure patterns of farmers in this area, the basic consumption demand expenditure patterns and the criteria defining payment ability levels. An index analysis method for water price bearing capacity is employed to calculate the range of water prices that are affordable for farmers and the suitable adjustment space. Specific conclusions are as follows:

Farmers in the Ebinur Lake Basin have the ability to pay for irrigation water price. Nearly $97 \%$ of farm households are able to pay the irrigation water, so it is feasible to raise the water price in the irrigation district of the Ebinur Lake Basin; the other 3\% of households will be the focus of water price reform in the future.

Farmers in the Ebinur Lake Basin have limited capacity to bear the rising water price. The proportion of water price to total output value, total cost, net benefit, and irrigation yield increase 
benefit all conform to the standard of suitable scope in China. However, when the proportion of water price to the benefit of irrigation increase exceeds $40 \%$ of the optimum extreme value, the water price must exceed the limit value. Therefore, a water price of $257 € / \mathrm{hm}^{2}$ should be defined as the limiting price, and water prices must be maintained within this range to achieve affordability for farmers.

The current water price in the irrigation area of the Ebihu Lake Basin is lower, and the space for raising water prices is larger. Average cost of water price only accounts for $6.1 \%$ of the total average production cost, which is difficult to guarantee the operation of farmland water conservancy projects. The current water price in Ebinur Lake Basin is $79 € / \mathrm{hm}^{2}$, with an average value of $127 € / \mathrm{hm}^{2}$; and the space for raising water price is $64 € / \mathrm{hm}^{2}$. Compared with the minimum affordability level for farmers, the current water price is far lower. The adjustable range of the unit water price is $0.014-0.042 € / \mathrm{m}^{3}$, with an average value of $0.024 € / \mathrm{m}^{3}$. In addition, the dynamic range of economic water price is $0.014-0.034 € / \mathrm{m}^{3}$ before water conservation, the adjustable space is $0.011 € / \mathrm{m}^{3}$, the unit water price after water conservation is $0.014-0.042 € / \mathrm{m}^{3}$, and the adjustable space is $0.018 € / \mathrm{m}^{3}$. Therefore, it fully shows that the reasonable scope of economic endurance of agricultural water users still has much potential for improvement, and the scope of adjustable space is also large.

This paper is based on the relevant literature, combined with the analysis of the current agricultural water price and the local natural economic situation in the Ebinur Lake Basin. In the analysis of farmers' affordability to irrigation water price, most of them are based on the analysis of grain crops. This paper analyzes wheat and cotton with relatively high yields around the Ebinur Lake Basin. However, the obtained results indicate farmers' ability to cover irrigation water prices, farmers' affordability of water price increases, and the current water price, which has a minor difference from the relevant results, indicating that in the actual irrigation process-whether planting grain crops or cash crops-the use of water price in the general irrigation area is uniform. Moreover, relevant studies are from the perspective of the agricultural water users, to explore the determination of water prices for agricultural water. It shows that the level of rural economic development, the actual income of farmers, and their living standards are the key factors of farmers' ability to pay for water. These key factors are reflected in this paper. It can be seen that the affordability of water prices is mainly affected by economic factors. Therefore, the farmers' economic affordability analysis in this paper is also more convincing.

To sum up, in the absence for specific water price affordability standards, through the analysis of the economic affordability to agricultural water users, we conducted an exploration of reasonable agricultural water price standards, aimed at providing a scientific evidence for water pricing reform in irrigation areas on the basis of not increasing the water cost burden of farmers.

Author Contributions: Conceptualization, L.W. and Z.S.; Writing-original draft, L.W.; Software, L.W.; Data curation, L.W. and Y.M.; Funding acquisition, Z.S., S.Y. and Y.M.; Writing-review and editing, L.W., Z.S. and S.Y. All authors read and approved the final manuscript.

Funding: National Natural Science Foundation of China Xinjiang Joint Key Foundation Project: U1603241. National Natural Science Foundation Project: 41661036.

Conflicts of Interest: The authors declare no conflict of interest.

\section{References}

1. Yi, R.G.; Jiang, W.L. Research progress on the effect of agricultural water price. Chin. J. Agric. Resour. Reg. Plan. 2017, 38, 224-229.

2. Liu, Y.M.; Luo, B.L. Impact of water price policies on farmers' irrigation water use behavior based on farmers' behavior models. Math. Pract. Theory 2011, 41, 27-32.

3. Hu, Z.Q.; Zhu, D.X.; Xin, L.; Hou, L.W.; Wang, D.Y. Comparison study on the level of international agricultural modernization based on the method of generation gap of industry elements. Sci. Agric. Sin. 2018, 51, 1412-1420.

4. Cao, X.C.; Ren, J.; Wu, M.Y.; Guo, X.P.; Wang, W.G. Assessing agricultural water use effect of China based on water footprint framework. Trans. Chin. Soc. Agric. Eng. 2018, 34, 1-8. 
5. Wang, H.; Ruan, B.Q.; Shen, D.J. Water Price Theory and Practice for Sustainable Development; SciencePress: Beijing, China, 2003.

6. Lei, B.; Yang, S.; Gao, Z.Y.; Liu, Y.; Nian, Z.L. An analysis of the impact of water price reform on farmers' irrigation decision-making. China Rural Water Hydropower 2008, 5, 108-110.

7. Feng, G.Z. Thoughts on perfecting the formation mechanism of agricultural Water Price. Water Resour. Dev. Res. 2010, 8, 26-32.

8. Maimaitiyiming, R.; Yang, J.J.; Liu, W. Changing characteristics of potential evapotranspitation, air temperature and precipitation in Ebinur Lake Basin from 1957 to 2013. J. Glaciol. Geocryol. 2016, $38,69-76$.

9. Meng, X.Y.; Meng, B.C.; Wang, Y.J.; Liu, Z.H.; Ji, X.N.; Yu, D.L. Influence of climate change and human activities on water resources in Ebinur Lake in recent 60 Years. J. China Hydrol. 2015, 35, 90-96.

10. Jiang, Y.; Wang, X.F. Research on bearing capability of farmers on agricultural irrigation water price in MaNaSi River irrigation district. Water Sav. Irrig. 2008, 9, 23-26.

11. Abuzeid, M. Water pricing irrigated agriculture. Water Resour. Dev. 2001, 17, 527-538. [CrossRef]

12. Tyler, A.D.; Joshua, M.P. Integrating water resources and power generation: The energy-water nexus in Illinois. Appl. Energy 2016, 162, 180-189.

13. Latinopoulos, D. Multicriteria decision-making for efficient water and land resources allocation in irrigated agriculture. Environ. Dev. Sustain. 2009, 4, 329-343. [CrossRef]

14. Yaweny, C. The price elasticity of transferring agricultural water to industrial water during non-drought period in Taiwan. Paddy Water Environ. 2012, 10, 41-47.

15. Kunimistu, Y. Pricing for irrigation water on Japanese paddy-fields applicability of stochastic choice model. Environ. Econ. Investig. Assess. 2006, 98, 285-293.

16. Kanakoudis, V.; Gonelas, K.; Tolikas, D. Basic principles for urban water value assessment and price setting towards its full cost recovery-pinpointing the role of the water losses. J. Water Supply: Res. Technol.-AQUA 2011, 60, 27-39. [CrossRef]

17. Kanakoudis, V.; Gonelas, K. Developing a methodology towards full water cost recovery in urban water pipe networks, based on the "user-pays" principle. Procedia Eng. 2014, 70, 907-916. [CrossRef]

18. Kanakoudis, V.; Gonelas, K. Forecasting the residential water demand, Balancing full water cost pricing and non-revenue water reduction policies: the case of Kozani city in Greece. Procedia Eng. 2014, 89, 958-966. [CrossRef]

19. Kanakoudis, V.; Gonelas, K. The joint effect of water price changes and pressure management, at the economic annual real losses level, on the system input volume of a water distribution system. Water Sci. Technol. Water Supply 2015, 15, 1069-1078. [CrossRef]

20. Kanakoudis, V.; Gonelas, K. The optimal balance point between NRW reduction measures, full water costing and water pricing in water distribution systems: Alternative scenarios forecasting Kozani's optimal balance point. Procedia Eng. 2015, 119, 1278-1287. [CrossRef]

21. Huang, J.S. The connotation and task of water control in the new period-comrade Xi Jinping's learning experience of important water control thoughts. Water Resour. Dev. Res. 2014, 9, 17-23.

22. Luo, J.R.; Yuan, Q. Study on water price system of multi-objective water transfer project based on the perspective of water supply chain. Price Theory Pract. 2016, 5, 61-64.

23. Liu, Y.; Wang, Y.; Zhou, M.F.; Deng, X.Z. The impact of Zhangye's water price reform on the economy and water saving using water-land CGE model. Resour. Sci. 2016, 38, 1901-1912.

24. Wang, W.; Chen, X.Q.; Wang, X.; Ma, H.Y.; Sun, L. Study on terminal water price and farmer's bearing capacity of regional small-scale irrigation and water conservancy project. Water Sav. Irrig. 2013, 6, 58-60.

25. Yin, X.J.; Cai, G.Y. Farmers' willingness to pay for water and the influencing factors-A case study of Zhangye City in Heihe River Basin. J. Arid Land Resour. Environ. 2016, 30, 65-70.

26. Li, Y.; Kong, D.S.; Wu, L.; Jin, L.S. Farmers' willingness to save water on the assumption that agricultural water pricing reform is applied. Water Sav. Irrig. 2017, 2, 99-102.

27. Kanakoudis, V. Urban water use conservation measures. J. Water Supply: Res. Technol.-AQUA 2002, 51, 153-163. [CrossRef]

28. Kanakoudis, V. Ex-post evaluation of a water distribution network upgrading project. J. Water Supply Res. Technol.-AQUA 2008, 57, 195-202. [CrossRef] 
29. Zhang, R.; Zhang, M.X. Analysis of the consumption structure of rural residents in Northern JiangSu Province based on ELES model. Chin. J. Agric. Resour. Reg. Plan. 2017, 38, 36-40.

30. Chen, D.; Chen, J.; Hu, L.; Chen, Y.H. Application of ELES model to classify levels of farmers' payment ability for irrigation water price. Water Sav. Irrig. 2009, 7, 8-14.

31. Wang, X.Q.; Wang, J.H.; Gao, J.; Zhang, Y. Study on farmers' bearing capacity of water price rising in Guanzhong area of Shanxi Province. China Price 2016, 8, 70-72.

32. Zhao, Y.Y.; Luo, P.; Chu, G.H.; Niu, Y.H. An analysis of farmers' tolerance of irrigation water price in mountainous area. China Rural Water Hydropower 2014, 11, 147-150.

(C) 2019 by the authors. Licensee MDPI, Basel, Switzerland. This article is an open access article distributed under the terms and conditions of the Creative Commons Attribution (CC BY) license (http:/ / creativecommons.org/licenses/by/4.0/). 